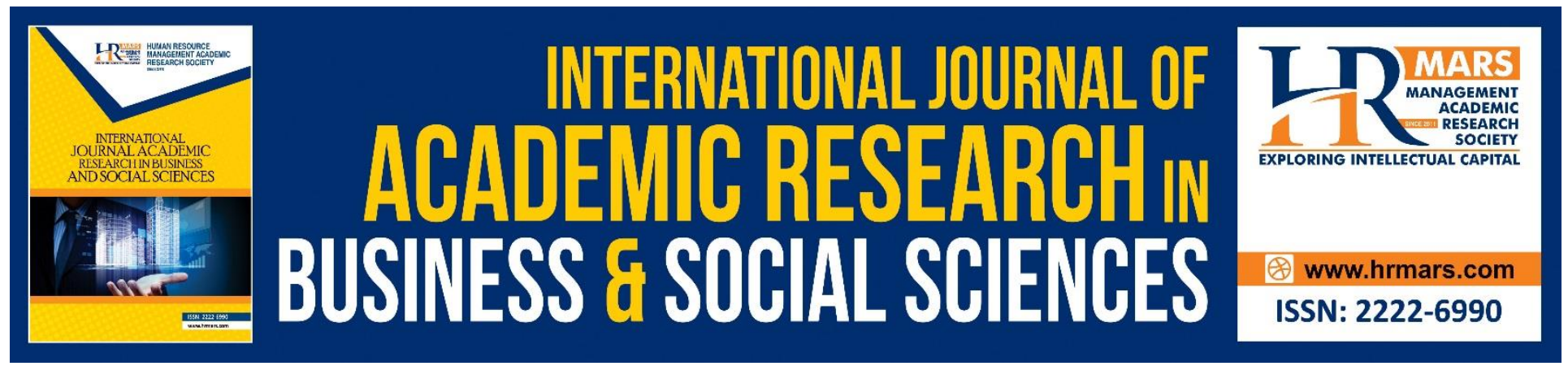

\title{
The Relationship between the Perception of Skills and the Readiness of Using AutoCAD Software among the Instructors of Construction Technology Program at Vocational College
}

\author{
Zuraifah Safiee, Zaliza Hanapi, Ummu Sakinah Subri, Yong Seh Sheh, \\ Muhamad Shazielan Sharif
}

To Link this Article: http://dx.doi.org/10.6007/IJARBSS/v9-i3/5728

DOI: $10.6007 /$ IJARBSS/v9-i3/5728

Received: 08 Feb 2019, Revised: 26 Feb 2019, Accepted: 11 March 2019

Published Online: 23 March 2019

In-Text Citation: (Safiee, Hanapi, Subri, Sheh, \& Sharif, 2019)

To Cite this Article: Safiee, Z., Hanapi, Z., Subri, U. S., Sheh, Y. S., \& Sharif, M. S. (2019). The Relationship between the Perception of Skills and the Readiness of Using AutoCAD Software among the Instructors of Construction Technology Program at Vocational College. International Journal of Academic Research in Business and Social Sciences, 9(3), 589-598.

Copyright: (C) 2019 The Author(s)

Published by Human Resource Management Academic Research Society (www.hrmars.com)

This article is published under the Creative Commons Attribution (CC BY 4.0) license. Anyone may reproduce, distribute, translate and create derivative works of this article (for both commercial and non-commercial purposes), subject to full attribution to the original publication and authors. The full terms of this license may be seen

at: http://creativecommons.org/licences/by/4.0/legalcode

Vol. 9, No. 3, 2019, Pg. 589 - 598

http://hrmars.com/index.php/pages/detail/IJARBSS

JOURNAL HOMEPAGE

Full Terms \& Conditions of access and use can be found at http://hrmars.com/index.php/pages/detail/publication-ethics 


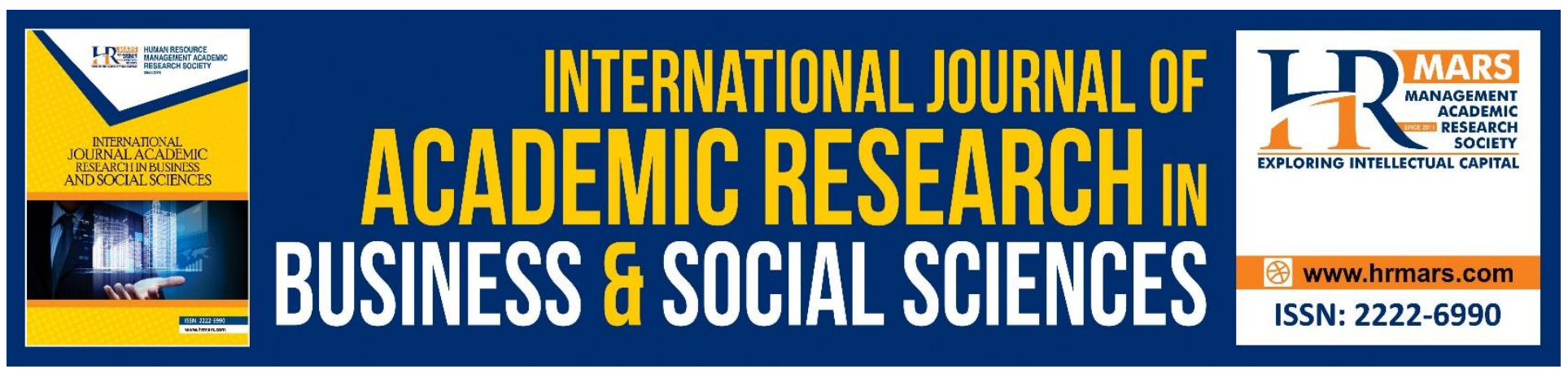

\title{
The Relationship between the Perception of Skills and the Readiness of Using AutoCAD Software among the Instructors of Construction Technology Program at Vocational College
}

\author{
Zuraifah Safiee, Zaliza Hanapi, Ummu Sakinah Subri, Yong Seh \\ Sheh, Muhamad Shazielan Sharif \\ Department of Engineering Technology, Faculty of Technical and Vocational, \\ Universiti Pendidikan Sultan Idris, 35900 Tanjong Malim, Perak, Malaysia
}

\begin{abstract}
Currently, there is a program called Construction Technology at Vocational College, which offered Computer-aided Design (CAD) courses. These courses require the creation of designs by using a CAD software application called AutoCAD. In accordance with that, each of the Construction Technology program instructors needs to increase their own values and importance that is in line with the implementation of the Vocational College Standard Curriculum (VCSC) which included the skills of using AutoCAD software. This software is used by the instructors through method demonstration in the teaching process in order to complete the module and produce related designs. This study was conducted to determine the relationship between the perception of skills and the readiness of using AutoCAD Software among the instructors of the Construction Technology program in their teaching. The respondents of the study consisted of a total of 193 instructors of the Construction Technology program throughout Peninsular Malaysia. This study used a questionnaire as its main instrument to collect data. The collected data were then analyzed descriptively and inferentially using The Statistical Package for Social Science (SPSS) software version 23.0. Correlation analysis shows that there is a strong and significant relationship between perception of skills and the readiness of using AutoCAD software in teaching with $r=0.845$ and $p<0.05$. This study can help to provide additional information to the people or organizations that are involved in the planning of the Construction Technology program and Vocational College Standard Curriculum (VCSC) which is very useful to help improve the competency of the instructors in the future.
\end{abstract}

Keywords: AutoCAD, Construction Technology, Vocational College, Skill, Readiness 


\section{Introduction}

The United Nations Educational, Scientific and Cultural Organization (UNESCO) define TVE as a field involving all aspects of the educational process, in addition to general education, related technological and scientific studies and the acquisition of practical skills, attitude, understanding and work-related knowledge in various sectors of economic and social life (Kementerian Pendidikan Malaysia, 2015). With the implementation of Vocational College Standard Curriculum (VCSC) at Vocational College, it has become a major challenge to all the instructors involved. It is unavoidable that all of Vocational College's instructors need to increase their values and importance in accordance with the implementation of VCSC. One of the essential skill required by the instructors of the Construction Technology program is the skill to be able to use the AutoCAD software. This software is used through method demonstration in the process of teaching and facilitating (TnF) to complete the module, which requires the students to generate designs related to the buildings as contained in the established curriculum.

The use of this software is also important and is needed in the construction of practical questions and theoretical items that involve diagrams. According to Baharuddin (2001), in order to master the field of Information Technology and Telecommunications, one should first identify and recognize the key elements that help to develop it. Meanwhile, Badri et. al (2014) reckoned that in order to comprehend and turning the potential benefits of the Information and Communications Technologies (ICT) into reality, it is important that the instructors received new technology integrations in the settings of their teaching practices. In the context of this study, the mastery and acceptance of knowledge and skills regarding the use of AutoCAD software will make the instructors more willing and prepared to carry out the process of teaching and facilitating.

Due to the implementation of Computer-aided Design (CAD) courses, which requires the use of AutoCAD software in producing designs, it has become a new challenge for the instructors of the Construction Technology program. The absence of textbooks for referral causes most of the nonoption teachers having difficulty to find the direction of the teaching that they want to convey. The instructors also felt that they are not competent enough if they cannot spontaneously or immediately answer questions from students.

Other than that, a learning module also needs to be formulated personally by the instructors based on the provided VCSC as a syllabus. Due to this matter, the instructors cannot ensure that the content of the self-sufficient lesson is adequate to determine the student's competency for their future career. A study conducted by Azizah (2016) regarding non-option teachers, suggests that the readiness of the non-option teachers that teach in VC is at a moderately high level in terms of the knowledge, skills, and attitudes. This situation will not happen if they can master the lesson that will be shared with the students.

If another aspect is taken into perspective, training is one of the important strategies in the organization to help increase the knowledge and skills of the employees that are relevant to the needs of the organization. This had been acknowledged by Gabureanu (2015), in which she revealed the importance of teacher training is to instill true skills into the teaching of their respective fields of 
expertise. A one-week training period is seen to be insufficient to make a teacher fully mastering the content of the theoretical lesson, not to mention when it involves a lesson that needs skill activities. There are even teachers who do not have the opportunity to attend the courses due to the time constraints that is filled with extremely packed activities. Hence, the researcher feels that this study should be carried out to examine the relationship between the skills and the readiness to use the AutoCAD software among the Vocational College instructors of the Construction Technology program.

\section{Literature Review}

Malaysian Teacher Standard Document (DSGM), (Kementerian Pendidikan Malaysia, 2009) or Teacher Training Division, 2009 has outlined the professional competencies that all teachers should fulfill and the essential requirements that should be provided by the agencies and training institutes to help teachers achieve a defined level of competency. This document is formulated as a guide and reference to teachers, teacher educators, the agencies and training institutes as part of the continuous effort to produce and sustain quality teachers. Based on the document, the standard cover three aspects, namely teacher professionalism, knowledge and understanding, teaching and learning skills. However, this writing focuses only on the aspects of teaching and learning skills.

\section{Teaching and Learning Skills}

The standard that has been outlined focuses on the ability of teachers to make plans, implement it, making assessment and evaluation of teaching and learning session, classroom management, and co-curriculum. Teaching and learning skills include aspects such as planning and the implementation of teaching and learning process that can ensure the student progress is at an optimum level. This standard is achieved when the teacher successfully masters the following skills:

i) Formulating the plan for teaching and learning,

ii) Execution of teaching and learning process,

iii) Monitoring, assessing and evaluating, and

iv) Classroom management

In the context of this study, the skills are focused on mastering the skill of using AutoCAD software in order to be able to convey it to the student in a way that is easily accepted and understood by them.

\section{The Readiness of the Instructors}

The readiness of the instructors is an important matter to be aware of before they enter the classroom to begin the process of TnF. Robiah (2000) explains that as a teacher who implements or executes the curriculum, making the necessary preparation along with the knowledge is very important before ones undertake the responsibility as an educator. A low level of readiness can pose several problems that lead to difficulty in achieving the objectives of teaching and learning. 
A study that had been conducted by Izzati (2013) on the readiness of vocational instructors who implemented the 'School Enterprise' Program in secondary school, found that the success of this program depends on the quality and the preparations made by the instructors from various aspects such as program knowledge, program management skills and attitude to implement the program. If the opposite occurs, then the program fails to execute properly. This statement is in line with Kariyev, Turganbayeva, and Slambekova (2015) research in Kazakhstan. In which through their research, they stated that the readiness of teachers to learn something is a condition for the students to develop their creative abilities, as it relies on the strength and professional structure of the teacher's own motivation. This will ultimately contribute to the readiness of teachers to face something new.

The truth is, to implement such matter of urgency, it should be through a secure and establish process of preparation. As an instructor, the success of TnF session depends on the ability to deliver the knowledge effectively, where the student will be able to understand, recollect, and apply the knowledge in any situation and whenever it is needed. The situation where the instructor is not ready or unprepared to teach can cause some problems that will disturb the process of TnF. Suriana (2012) in her research stated that teachers as educators should equip themselves with all key aspects such as knowledge, the skills, attitude, and emotions. This statement is in accordance with Zaiha (2014) point of view, which explains that teachers not only does need the skills and knowledge in their teaching, but they also need to have a personality that can be proud of, emulated and followed by their students.

In addition, aside from helping to spread the knowledge, each behaviour of a teacher will be set as an example and a model for the students. Mok (2002) defines teachers as educators who become an important asset to the cultural heritage and knowledge for the future progress of the country. Hence, the strength of mental, physical, and emotions are crucial as well as knowledge and skills in the preparation of their existence in the field of education.

\section{The Relationship Between the Skills and the Readiness of Instructors}

The offering of skill courses such as at VC requires highly skilled educators in every field that are being represented. Roslan (2014) argues that the need to master the knowledge of teaching skills, profound knowledge about the content of teaching and the attitude of a teacher seen during class and beyond the teaching time should be mastered so that the teaching and learning process can be delivered more effectively. This statement is supported by Syed (2014) in his study on the competency of VC educators, which stated that the theoretical proficiency alone is insufficient in order to produce skilled students. The teachers need to have the technical skills to facilitate their practice in teaching and learning.

Therefore, the importance of having teacher's skills is seen as having the same degree of importance as having the knowledge about each of their respective teaching fields. The research that had been conducted in Indonesia by Rohayani, Kurniabudi, and Sharipuddin (2015) regarding $e$ learning at the higher education center, found that besides attitude, skills are the most important factor to establish the readiness of learning the e-learning. They further added that each institution has a different level of readiness. Hence, each institution needs to be more careful in determining the critical factors that need to be focused on when measuring their e-learning readiness. This is to obtain accurate information that illustrates the real state of their institutions. This is in line with the 
research conducted by Prakash and Shaji (2017) in India, who found that vocational educators need to have basic engineering skills and pedagogical skills to be the best presenters and communicators in front of the students. They also need professional skills in both fields, as skilled workers and as educators. He concludes that vocational teachers need to improve their teaching skills and technical skills to recognize what is important for students so that they can motivate students to learn.

This suggests that skills are very much important which is needed generally in each skill instructors especially in each of VC instructors. These skills varied according to the courses offered at the institution. The management together with the instructors need to ensure that the existing skills are always ready to be improved and are in tune with the current needs.

\section{Methodology}

This study uses quantitative approaches through survey method. The survey conducted aims to explain about the phenomenon that is taking place. Furthermore, it is also selected to quantitatively measure the relationship between independent variables and dependent variables. The inferential statistical method was used to analyze the data from the sample of the study and then, further generalization was made on the respondents of the study. According to Noraini (2010), survey research works to get answers for the following questions; whether the problem really exists, what kind of problem is encountered, how serious the problem is, and whether the problem requires attention or not.

To achieve the objectives of this study, Pearson's correlation coefficient analysis was used to examine the relationship between the skill constructs and the readiness of using AutoCAD software among the Construction Technology instructors in VC during their teaching session. This design is best used when researchers try to connect two or more variables in order to identify if they have an influence on each other (Creswell, 2012).

In this study, the population consists of Construction Technology instructors from VC located in Peninsular Malaysia. There is a total of 38 VCs that offer the Construction Technology program in Peninsular Malaysia (source: Technical and Vocational Education Division) which recorded a total of 351 instructors of the Construction Technology program. In order to determine the size of the sample that will be involved in this study, the researcher used the Krejcie dan Morgan (1970) formula based on the Table Determining Sample Size for Research Activities.

From the total number of the respondents, only 186 respondents were selected using stratified random sampling techniques. This random technique is used because there is a disproportionate distribution of sub-population, which is the number of Construction Technology instructors are not the same according to each zone (Othman, 2013). However, the total number of questionnaires being distributed was 260 by considering $40 \%$ of the surplus from the number of sample surveys in the event of loss during posting or are not returned by the respondents (Salkind, 2012).

This study was conducted using a questionnaire in which it was constructed based on the modifications made from previous research items. That is because each item from previous research has been proven its validity and reliability. Besides that, the researchers also made references to the syllabus of the AutoCAD course offered at VC when constructing the questionnaire. The distribution 
INTERNATIONAL JOURNAL OF ACADEMIC RESEARCH IN BUSINESS AND SOCIAL SCIENCES

Vol. 9, No. 3, March, 2019, E-ISSN: 222 2-6990 ¿ 2019 HRMARS

of the questionnaire includes a constructive perception of skills in using AutoCAD software and the readiness to use AutoCAD software.

\section{Findings}

Pearson's correlation coefficient analysis is used to identify the relationship between the perception of skills and the readiness of using AutoCAD software among the Construction Technology instructors in their teaching. The result of the analysis shows that there is a strong and significant relationship between the perception of skills and the readiness of using AutoCAD software among the Construction Technology instructors in their teaching with the value of $r=0.845$ and $p<0.05$. This strong positive correlation shows that as skills increase, then the readiness will also increase.

Table 1. The Relationship Between the Perception of Skills and the readiness of Using AutoCAD Software among the Construction Technology Instructors in Their Teaching.

\begin{tabular}{|l|l|c|c|c|c|}
\hline Variable & Mean & Standard Deviation & $r$ & $p$ & $\begin{array}{l}\text { The strength of } \\
\text { relationship }\end{array}$ \\
\cline { 1 - 2 } Skills & 42.01 & 9.85 & $0.845^{* *}$ & .000 & Strong \\
\hline Readiness & 34.68 & 9.02 & 00 & \\
\hline
\end{tabular}

**significant correlation at level 0.01 (2-tailed)

Based on the value of $r=0.845$, the variance value obtained is $r^{2}=0.714$. This indicates that $71.4 \%$ of readiness are due to their own skills.

\section{Discussions and Conclusion}

Aside from knowledge, skills are one of the key elements that are needed by everyone who is teaching in the field of technical and vocational education. At VC, the skills comprise $70 \%$ of the total TnF activities. In this study, the skills studied are limited to the skill of using AutoCAD software and the findings are based only on the perception of the instructors about their skills in using the software.

Previously, there have been some studies conducted regarding the skills among the teaching staff and found that all of it has come to one agreement in which the skill is very crucial and is needed by all the educators especially the vocational educators. Among them are the study by Roslan (2014), Syed (2014), Rohayani, Kurniabudi, and Sharipuddin (2015) and Prakash Pillai (2017). The mastery of theories needs to be in tune with the technical skills in order to facilitate the practical work in the teaching process. Additionally, vocational instructors that have proficiency in engineering and possess pedagogical skills can be the best presenter and communicators in front of the students.

Other than knowledge, the skills are also seen as one of the important aspects in determining the success of a teaching process. In fact, the situation at VC is more inclined towards skilled because when the skills are mastered, then indirectly the knowledge will also be presented. Malaysian Standard Teacher Document has highlighted that the standards of these skills are achieved only when teachers can master the skills such as planning, implementing, monitoring, evaluating and managing classes. 
There are several studies that have been conducted and found that there is a significant relationship between the skills and the readiness to teach. Among them is the study by Khadijah (2013) who discovered that the readiness of future teacher for Reka Cipta subject is high when their knowledge and skills are high. Additionally, Roslan (2014) and Prakash Pillai (2017) agreed that teaching can be effectively delivered if the instructors were able to master and exercise practical teaching skills and knowledge in the subject matter. Meanwhile, Rohayani et al. (2015) states that besides attitude, skills are the most important factor in creating the readiness to learn e-learning and Yağcı, Sırakaya, and Özüdoğru (2015) found that there were differences in the readiness between new teachers and more experienced teachers, although there were no differences in attitudes between the two groups. All of these studies are relating the skills with the readiness to teach and the ability to convey the knowledge either practically or in theory effectively.

Based on the presented discussion, it is clear that skills and readiness are often being discussed as the main topic of a study which reviews the effectiveness of TnF process as well as knowledge and attitude. A recent study by Petco, Prasse, and Cantieni (2018) confirm that technology integration in education depends on the readiness of the teacher itself and is further influenced by the readiness of schools. The readiness of teachers to integrate technology in education is based on the skills and beliefs that they perceived. Meanwhile, the readiness of schools is to include educational technology resources in the classroom, the importance of technology integration, the clarity of the purpose, and the support from the head of the department. Furthermore, a study regarding the implementation of School-based Assessment (SBA) shows that the readiness of teachers to carry out SBA was closely related to the courses they had received and learned regarding SBA and also their skills in order to implement them (Siti, Zaliza, Tee, Suriani, \& Ridzwan, 2018). Even though these studies do not have any relationships that lead to the use of AutoCAD in teaching, it was still closely related to TnF process and mostly in the vocational field.

In the institution of technical and vocational education, technical instructors are the most important individuals as they are the one who needs to be attuned and responsive to any kind of changes that is happening in the industry in order to produce highly skilled graduates which can fulfill the requirement and the needs of the industry and also for the future of the country. Their tasks are not only to deliver knowledge and skills to the students, but they also carry the responsibility to instill interest, and developing talents and abilities of the students. If the instructor is inexperienced, it is difficult for them to provide knowledge and skills that comply with the needs of the industry. Hence, the role and competency of the instructors are very crucial in order to produce a skilled workforce and at the same time is in accordance with the needs of the country's development so that it can be well and effectively implemented.

\section{Acknowledgement}

We wish to express our gratitude to Educational Planning and Research Division, Ministry of Education and Technical and Vocational Education Division for allowing us to conduct this study. Sincerely thanks to the Department of Engineering Technology, Faculty of Technical and Vocational, Universiti Pendidikan Sultan Idris for the opportunity and huge moral support. Thank you to all experts for their assistance and guidance on this study. 
INTERNATIONAL JOURNAL OF ACADEMIC RESEARCH IN BUSINESS AND SOCIAL SCIENCES

Vol. 9, No. 3, March, 2019, E-ISSN: 222 2-6990 @ 2019 HRMARS

\section{Corresponding Author}

Zuraifah Safiee

Department of Engineering Technology, Faculty of Technical and Vocational, Universiti Pendidikan Sultan Idris, 35900 Tanjong Malim, Perak, Malaysia

Email: zuraifah.s@gmail.com

\section{References}

Azizah A. (2016). Pelaksanaan Mata Pelajaran Kemahiran Vokasional di Kolej Vokasional Dalam Kalangan Guru-guru Bukan Opsyen Kemahiran. Masters Thresis, Universiti Teknologi Malaysia.

Badri, M., Al Rashedi, A., Yang, G., Mohaidat, J., \& Al Hammadi, A. (2014). Technology readiness of school teachers: An empirical study of measurement and segmentation. Journal of Information Technology Education Research, 13, 257-275.

Baharuddin A. (2001). Universiti Teknologi Malaysia's teacher education students learning about ICT using ICT. Skudai: Universiti Teknologi Malaysia.

Creswell, J. W. (2012). Educational research: Planning, conducting, and evaluating quantitative and qualitative research (4th Ed). Boston: Pearson Education.

Gabureanu S. (2015). Teacher Training for Embedding Life Skills into Vocational Teaching. In The 6th International Conference Edu World 2014 "Education Facing Contemporary World Issues" (pp. 814-819). Romania: Elsevier Ltd. https://doi.org/10.1016/j.sbspro.2015.02.215

Izzati K. (2013). Kesediaan Guru Mata Pelajaran Aliran Vokasional Melaksanakan Program School Enterprise di Sekolah Menengah Teknik Zon Selatan. Masters Thesis, Universiti Putra Malaysia.

Kariyev, A., Turganbayeva, B., Slambekova, T., Zheldybayeva, B., \& Kabdualiyeva, A. (2015). Model of Formation of Teacher's Readiness to Learning on The Base of Interactive Methods as The Conditions Of Creation of Students Abilities. In 2nd Global Conference on Psychology Researches (Vol. 190, pp. 353-357). Kazakhstan: Eisevier Ltd.

Kementerian Pendidikan Malaysia. (2009). Standard Guru Malaysia. Putrajaya: Bahagian Pendidikan Guru.

Kementerian Pendidikan Malaysia. (2015). Malaysia Education Blueprint 2015-2025. Putrajaya: Kementerian Pendidikan Malaysia.

Krejcie, R. V, \& Morgan, D. W. (1970). Determining Sample Size For Research Activities. Educational and Psychological Measurement, 38(30), 607-610.

Mok S. S. (2002). Pengurusan Bimbingan \& Kaunseling. Kuala Lumpur: Universiti Malaya.

Noraini I. (2010). Penyelidikan dalam Pendidikan. Kuala Lumpur: McGraw-Hill (Malaysia). Othman T. (2013). Asas Penulisan Tesis Penyelidikan \& Statistik. Serdang: Penerbit UPM.

Petco, D., Prasse, D., \& Cantieni, A. (2018). The Interplay of School Readiness and Teacher Readiness for Educational Technology Integration A Structural Equation Model. Interdisciplinary Journal of Practice, Theory and Applied Research, 35(1), 1-18. https://doi.org/https://doi.org/10.1080/07380569.2018.1428007

Prakash P, \& Shaji B. (2017). Analysis of Training Needs of Vocational Trainers in Skill DevelopmentA Case Study From Vhse, Kerala. International Seducation and Research Journal, 3(1), 9-11.

Robiah S. (2000). Kualiti Pengajaran Dan Pembelajaran Universiti Tempatan. Jurnal Akademika, 57, 25-40. 
Rohayani, A. H. H., Kurniabudi, \& Sharipuddin. (2015). A Literature Review: Readiness Factors to Measuring e-Learning Readiness in Higher Education. Procedia Computer Science, 59, 230-234.

Roslan A. H. (2014). Kompetensi Guru Bukan Opsyen yang Mengajar Kemahiran Teknikal di Kolej Vokasional Negeri Pahang. Masters Thesis, Universiti Tun Hussein Onn Malaysia.

Salkind, N. J. (2012). Exploring Research (8th Ed). United States: Pearson Education.

Khadijah S. R. (2013). Kesediaan Bakal Guru DPLI Terhadap Mata Pelajaran Reka Cipta Untuk Mengajar Di Sekolah Menengah. Masters Thesis, Universiti Tun Hussein Onn Malaysia.

Siti N. A. M., Zaliza H., Tee, T. K., Suriani M., \& Ridzwan C. R. (2018). The Wilingness , Acceptance And Operation of Design and Technology Teachers on Practice in School Based Assessment. Sains Humanika, 10(3), 89-94.

Suriana I. (2012). Kesediaan Guru Terhadap Pelaksanaan Mata Pelajaran Reka Bentuk dan Teknologi (RBT) Sekolah Rendah di Malaysia. Masters Thesis, Universiti Tun Hussein Onn Malaysia.

Syed J. S. A. (2014). Kompetensi Guru Dalam Pengajaran Amali Teknologi Pembinaan di Kolej Vokasional. Masters Thesis, Universiti Tun Hussein Onn Malaysia.

Yagci, M., Sırakaya, D. A., \& Özüdoğru, G. (2015). The Investigation of Attitude and Readiness of Information and Communication Technologies Pre-service Teachers Toward Web Based Learning. Procedia - Social and Behavioral Sciences, 174, 1099-1106.

Zaiha N. H. (2014). Kompetensi Guru Dalam Pengajaran Amali Reka Bentuk dan Teknologi di Sekolah Rendah Daerah Batu Pahat. Masters Thesis, Universiti Tun Hussein Onn Malaysia. 